\title{
IPTEKS PENGHITUNGAN PAJAK PENGHASILAN TERUTANG BERDASARKAN PP NOMOR 23 TAHUN 2018 DI KELURAHAN MALENDENG KECAMATAN PAAL 2 KOTA MANADO
}

\author{
Novi Swandari Budiarso ${ }^{1}$, Winston Pontoh ${ }^{2}$, Heince R. N. Wokas ${ }^{3}$ \\ ${ }^{1,2,3}$ Program Studi Pendidikan Profesi Akuntansi, Fakultas Ekonomi dan Bisnis, Universitas Sam Ratulangi, Jl. \\ Kampus Bahu, Manado,95115, Indonesia \\ E-mail : novi.sbudiarso@unsrat.ac.id
}

\begin{abstract}
One source for implementing national development is tax revenue that reaches $75 \%$ of current state revenues, with the existence of taxes, the state can carry out development aimed at the welfare of the community itself. In fact, the voluntary awareness and concern of taxpayers is very difficult to realize if it is not forced, meaning that people are required to pay taxes in order to build a national economy. Tax collection itself still has many obstacles and challenges that come from the community itself, for example; awareness of paying taxes is still lacking in the community, the crisis of public confidence in the government and understanding of taxation itself is still very poor in terms of calculations, payments up to reporting (in this case Calculating Own Taxes - Self Assessment System), so often cause obstacles in paying taxes themselves. Malendeng, Paal 2 Subdistrict, Manado City as part of an interesting autonomous region to be observed specifically considering 1,305 taxpayers, land and building taxes, but the realization of the is only around $60.53 \%$, namely from the small industries and household handicrafts, the medium and large industrial sectors and the service sector as well as tax revenues on the control of economic assets of the community. The problems are 1) Lack of knowledge, especially small businesses about taxes related to partner businesses and 2) Lack of ability to do tax calculation and reporting related to partner businesses, while the solutions offered are 1) Transfer of knowledge about taxes in connection with small businesses and, 2) Transfer expertise regarding tax calculation and reporting related to partner business. The method used is 2 (two) ways, namely lecture and training, lecture method with presentation techniques of material concerning taxation material, especially those involving small entrepreneurs, namely Income Tax. The training method is carried out with a simple case study of the calculation and reporting of income tax.The results achieved were an increase in the knowledge of the Malendeng villagers about income tax for micro, small and medium enterprises and an increase in the community's ability to calculate and report income taxes.
\end{abstract}

Keywords : Income Tax, Small Industries, Self Assessment System

\section{PENDAHULUAN}

Salah satu tujuan negara adalah untuk mewujudkan kesejahteraan bangsa dan pembangunan vital lainnya, hal ini dapat dilaksanakan lewat pembangunan nasional yang merata bagi seluruh masyarakat. Salah satu sumber untuk melaksanakan pembangunan nasional adalah penerimaan pajak yang merupakan iuran rakyat kepada kas negara berdasarkan undang-undang (yang dapat dipaksakan) dengan tiada mendapat jasa timbal balik (kontraprestasi) yang langsung dapat ditunjukan dan yang digunakan untuk membayar pengeluaran umum (Waluyo 2011: 2; Mardiasmo 2016:1). Dengan adanya pajak, maka negara dapat melakukan pembangunan yang bertujuan untuk kesejahteraan masyarakat itu sendiri. Akan tetapi, pada prakteknya, beberapa tahun terakhir penerimaan pajak masih rendah. Bukan saja penerimaan pajak nasional yang belum optimal, rasio pajak juga 
mengalami penurunan. Tingkat kepatuhan masyarakat Indonesia dapat dilihat dari tingkat tax ratio yaitu $11 \%$, jika dibandingkan dengan negara negara tetangga Malaysia yang di atas $14 \%$ sampai $15 \%$, Vietnam dan Singapura 16\%. Pemungutan pajak itu sendiri masih memiliki banyak halangan dan tantangan yang berasal dari masyarakat itu sendiri, misalnya ; kesadaran akan membayar pajak masih kurang dalam masyarakat, artinya kesadaran wajib pajak berpengaruh terhadap kepatuhan wajib pajak (Safri, 2013), kemudian krisis kepercayaan publik pada pemerintah dan juga pemahaman akan perpajakan itu sendiri masih sangat kurang baik dari segi perhitungan, pembayaran sampai pada pelaporannya (dalam hal ini. Menghitung Pajak Sendiri - Self Assessment System), sehingga tak jarang menimbulkan hambatan dalam pembayaran pajak itu sendiri.

Salah satu sumber untuk melaksanakan pembangunan nasional adalah penerimaan pajak yang mencapai $75 \%$ penerimaan negara saat ini, dengan adanya pajak maka negara dapat melakukan pembangunan yang bertujuan untuk kesejahteraan masyarakat itu sendiri. Dominasi pajak sumber penerimaan merupakan satu hal yang sangat wajar, ketika sumber daya alam, khususnya minyak bumi tidak bisa lagi diandalkan. Penerimaan dari suatu sumber daya alam mempunyai umur relatif terbatas yang suatu saat akan habis dan tidak bisa diperbaharui lagi. Hal ini berbeda dengan pajak, sumber penerimaan ini mempunyai umur tidak terbatas, apalagi seiring dengan bertambahnya jumlah penduduk, dan perubahan struktur ekonomi dari ekonomi agragris ke ekonomi industri maka akan semakin besar pula penerimaan negara dari sektor pajak (Darmayanti, 2012). Pada kenyataannya kesadaran dan kepedulian sukarela Wajib Pajak sangat sulit untuk diwujudkan seandainya tidak dipaksakan dengan undang undang dan sanksi (Dharma dan Ariyanto, 2014), artinya masyarakat dituntut untuk membayar pajak guna membangun perekonomian nasional. Pemungutan pajak itu sendiri masih memiliki banyak halangan dan tantangan yang berasal dari masyarakat itu sendiri, misalnya ; kesadaran akan membayar pajak masih kurang dalam masyarakat, krisis kepercayaan publik pada pemerintah dan juga pemahaman akan perpajakan itu sendiri masih sangat kurang meskipun pemerintah telah melakukan reformasi perpajakan dengan diterbitkannya Undang-Undang Nomor 36 Tahun 2008 tentang Ketentuan Umum dan Tata Cara Perpajakan. Masalah yang sering muncul, baik dari segi perhitungan, pembayaran sampai pada pelaporannya (dalam hal ini Menghitung Pajak Sendiri - Self Assessment System), sehingga tak jarang menimbulkan hambatan dalam pembayaran pajak itu sendiri.

\section{TINJAUAN PUSTAKA \\ 2.1. Pajak}

Pajak merupakan iuran yang terutang oleh masyarakat kepada negara, dan merupakan kewajiban yang dipaksakan dengan Undang-Undang tanpa imbalan langsung, dan berfungsi sebagai sumber pendapatan negara serta bertujuan mengatur bidang-bidang tertentu(Mardiasmo 2016:1). Sifat pajak yang memaksa dapat menimbulkan perlawanan dari wajib pajak, karena itu pemungutan pajak harus memenuhi syarat :

a. Keadilan, pengenaan pajak harus sesuai dengan kemampuan seseorang.

b. Berdasarkan Undang-Undang, pemungutan pajak harus didasarkan pada Undang-Undang yang menjabarkan dengan jelas hak dan kewajiban wajib pajak.

c. Tidak mengganggu perekonomian, pemungutan pajak tidak boleh memberatkan wajib pajak, sehingga mengganggu kegiatan produksi dan perdagangan.

d. Efisien, biaya pemungutan pajak sebaiknya tidak melebihi hasil pemungutan pajak.

e. Sederhana, sistem dan mekanisme pajak yang rumit dapat menimbulkan perlawanan pajak karena itu Undang Undang yang mengatur sistem perpajakan sebaiknya dibuat sederhana dan mudah dipahami masyarakat (Mardiasmo, 2016:4). 
Sistem pemungutan pajak merupakan mekanisme yang digunakan untuk menghitung besarnya pajak terutang wajib pajak yang harus dibayar kepada negara. Sistem pemungutan pajak, yaitu:

1. Self Assessment System

Sistem ini memberikan kewenangan kepada wajib pajak untuk menghitung, membayar, melaporkan sendiri jumlah pajak terutang menurut peraturan perundang-undangan perpajakan yang berlaku.

2. Official Assessment System

Aparatur perpajakan menentukan jumlah pajak terutang setiap tahunnya berdasarkan undang-undang perpajakan. Kegiatan menghitung dan memungut pajak merupakan kewenangan aparatur perpajakan.

3. With Holding System

Sistem ini memberikan wewenang kepada pihak ketiga untuk menentukan besarnya pajak yang terutang oleh wajib pajak. Pihak ketiga ditunjuk sesuai peraturan perundangundangan perpajakan, keputusan presiden dan peraturan lainnya untuk melakukan pemotongan, penyetoran, dan mempertanggungjawabkan pajak terutang wajib pajak.

Salah satu jenis pajak adalah Pajak Penghasilan ( $\mathrm{PPh})$, yaitu pajak yang dikenakan atas penghasilan yang diterima atau diperoleh wajib pajak dalam satu tahun pajak yang dapat dikenakan secara berkala dan berulang-ulang (Suandy, 2011:36; Resmi, 2014:74). Pasal 17 Undang-Undang PPh menjelaskan tentang subjek pajak dan tarif pajak, Pajak Penghasilan. Subjek pajak terdiri atas wajib pajak orang pribadi dalam negeri dan wajib pajak badan dalam negeri/Bentuk Usaha tetap (BUT). Tarif pajak wajib pajak orang pribadi mengacu pada Undang-Undang Nomor 36 Tahun 2008, yang dikenakan atas penghasilan bersih setelah dikurangi Penghasilan Tidak Kena Pajak, dalam satu tahun pajak. Tarif pajak wajib pajak badan adalah $25 \%$, besarnya penghasilan kena pajak ditentukan berdasarkan pembukuan. Berdasarkan Undang-Undang Nomor 36 Tahun 2008, apabila wajib pajak memilih tidak membuat pembukuan, maka penghasilan kena pajak berdasarkan Norma Penghitungan Penghasilan Neto. Penghasilan dibagi menjadi 2 jenis berdasarkan jumlah peredaran bruto, yaitu: 1) Peredaran bruto sampai dengan Rp. 50.000.000.000 mendapat pengurangan tarif sebesar 50\% dari tarif yang berlaku dan dikenakan atas penghasilan kena pajak dari peredaran bruto sebesar Rp 4.800.000.000. 2) Peredaran bruto di atas Rp 50.000.000.000 adalah $25 \%$.

\subsection{Pajak Penghasilan Final Berdasarkan Peraturan Pemerintah Nomor 23 Tahun 2018}

Peraturan Pemerintah (PP) Nomor 23 Tahun 2018 merupakan revisi atas Peraturan Pemerintah (PP) Nomor 46 Tahun 2013. Beberapa pokok penting yang diatur dalam PP Nomor 23 Tahun 2018 tentang Pajak Penghasilan atas Penghasilan dari usaha yang diterima atau diperoleh Wajib Pajak yang memiliki peredaran bruto tertentu adalah:

1. Mekanisme penghitungan PPh Final

$\mathrm{PPh}$ terutang sebulan adalah Tarif dikali peredaran bruto, tarif yang berlaku adalah $0,5 \%$.

2. Tarif PPh Final 0,5\% bersifat optional

Wajib pajak dapat memilih untuk mengikuti tarif $\mathrm{PPh}$ final $0,5 \%$ atau menggunakan tarif yang mengacu pada pasal 17 Undang-Undang Nomor 36 Tahun 2008 tentang Pajak Penghasilan.

3. Pengenaan tarif PPh Final 0,5\% memiliki batas waktu

Pemerintah memberikan batas waktu bagi wajib pajak yang ingin menggunakan tarif $\mathrm{PPh}$ Final $0,5 \%$ sebagai berikut.

1. 7 tahun pajak bagi wajib pajak orang pribadi

2. 4 tahun bagi wajib pajak berbentuk koperasi, perseroan komanditer atau firma

3. 3 tahun pajak bagi wajib pajak badan berbentuk perseroan terbatas. 
Setelah batas waktu tersebut berakhir maka wajib pajak kembali menggunakan pasal 17 Undang-Undang Nomor 36 Tahun 2008.

4. Wajib pajak yang dikenai PPh Final $0,5 \%$ memiliki peredaran bruto di bawah Rp 4.800.000.000.

Batas penghasilan wajib pajak yang dikenai PPh Final adalah Rp 4.800.000.000.

5. Wajib pajak yang tidak dapat dikenai PPh Final 0,5\%.

a. Wajib pajak orang pribadi dengan penghasilan yang diperoleh dari jasa sehubungan dengan pekerjaan bebas.

b. Wajib pajak dengan penghasilan yang diperoleh di luar negeri yang pajaknya terutang atau telah dibayar di luar negeri.

c. Wajib pajak yang penghasilannya telah dikenai $\mathrm{PPh}$ yang bersifat final.

d. Wajib pajak dengan penghasilan yang dikecualikan sebagai objek pajak

Besarnya peredaran bruto tertentu merupakan jumlah peredaran bruto dalam I (satu) tahun dari Tahun Pajak terakhir sebelum Tahun Pajak bersangkutan, yang ditentukan berdasarkan keseluruhan peredaran bruto dari usaha, termasuk peredaran bruto dari cabang.

\subsection{Usaha Mikro, Kecil dan Menengah}

Batas penghasilan wajib pajak yang dikenai PPh Final pada PP Nomor 23 Tahun 2018 adalah di bawah Rp 4.800.000.000. Meskipun tidak dinyatakan secara ekspilist, namun PP ini merujuk pada Usaha Mikro Kecil Menengah (UMKM). Berdasarkan Undang-Undang Nomor 20 Tahun 2008 tentang UMKM, maka yang dimaksud usaha mikro adalah usaha produktif milik orang perorangan dan atau badan usaha perorangan. Usaha kecil adalah usaha ekoomi produktif yang berdiri sendiri yang dimiliki orangan perorangan atau badan usaha yang bukan merupakan anak perusahaan atau bukan cabang yang dimiliki, dikuasai, atau menjadi bagian dari usaha menengah atau usaha besar. Usaha menengah adalah usaha ekonomi produktif yang berdiri sendiri, yang dilakukan oleh orang perseorangan atau badan usaha yang bukan merupakan anak perusahaan atau cabang perusahaan yang dimiliki, dikuasai, atau menjadi bagian baik langsung maupun tidak langsung dengan usaha kecil atau usaha besar.

Kriteria UMKM dapat dikelompokkan menurut jumlah aset dan omzet yang dimiliki sebuah usaha.

a. Usaha mikro adalah usaha yang memiliki kekayaan bersih paling banyak Rp 50.000.000, tidak termasuk tanah dan bangunan tempat usaha, serta memiliki hasil penjualan tahunan paling banyak Rp 300.000.000.

b. Usaha kecil adalah usaha yang memiliki kekayaan bersih lebih dari Rp 50.000.000 sampai dengan paling banyak Rp 500.000.000 tidak termasuk tanah dan bangunan tempat usaha, serta memiliki hasil penjualan tahunan lebih dari Rp 300.000.000 sampai dengan paling banyak Rp 2.500.000.000.

c. Usaha menengah adalah kegiatan usaha yang memiliki kekayaan bersih lebih dari Rp 500.000.000 sampai Rp 10.000.000.000 tidak termasuk tanah dan bangunan tempat usaha, serta memiliki hasil penjualan tahunan lebih dari Rp 2.500.000.000 sampai dengan paling banyak Rp 50.000.000.000.

\section{METODE DAN TEKNIK PENERAPAN IPTEKS}

\subsection{Metode Penerapan Ipteks}

Guna memberikan solusi bagi permasalahan mitra, maka metode penerapan ipteks adalah ceramah dan pelatihan. Metode ini diterapkan karena mitra merupakan masyarakat dengan tingkat pemahaman pajak yang rendah. Metode ceramah dapat membuka wawasan dan meningkatkan pengetahuan tentang perpajakan pada mitra, sedangkan pelatihan merupakan penerapan atas materi ceramah yang telah dipaparkan. 


\subsection{Teknik Penerapan Ipteks}

Berdasarkan metode penerapan ipteks maka teknik penerapan ipteks adalah sebagai berikut.

a. Melakukan presentasi dengan materi Pajak Penghasilan, dilanjutkan dengan diskusi dan bagi pendapat mengenai masalah dan upaya dalam penerapan Pajak Penghasilan usaha mikro, kecil dan menengah, guna pengembangan usaha yang lebih baik.

b. Memberikan pemahaman tentang pentingnya tata administrasi keuangan dalam usaha kecil untuk kemudahan perhitungan dan pelaporan perpajakan.

c. Memberikan pengetahuan dasar atas perhitungan dan pelaporan pajak dengan menggunakan software komputer sederhana yang lebih aplikatif dalam usaha kecil di bidang usaha kecil.

d. Memberikan pengetahuan dasar manajerial usaha kecil serta pemanfaatan informasi keuangan untuk perhitungan pajak.

e. Memberikan pelatihan studi kasus dengan kasus perhitungan dan pelaporan pajak sederhana

\section{PEMBAHASAN}

\subsection{Gambaran Objek Penerapan Ipteks}

Kelurahan Malendeng merupakan bagian dari Kecamatan Tikala. Sebelah utara berbatasan dengan Perkamil/Paldua, sebelah selatan berbatasan dengan Paal IV, sebelah timur berbatasan dengan Maumbi dan sebelah barat berbatasan dengan Perkamil.

\subsection{Pembahasan}

Salah satu tujuan negara adalah untuk mewujudkan kesejahteraan bangsa dan pembangunan vital lainnya, hal ini dapat dilaksanakan lewat pembangunan nasional yang merata bagi seluruh masyarakat. Salah satu sumber untuk melaksanakan pembangunan nasional adalah penerimaan pajak yang merupakan iuran rakyat kepada kas negara berdasarkan undang-undang (yang dapat dipaksakan) dengan tiada mendapat jasa timbal balik (kontraprestasi) yang langsung dapat ditunjukan dan yang digunakan untuk membayar pengeluaran umum (Waluyo 2011: 2; Mardiasmo 2016:1). Dengan adanya pajak, maka negara dapat melakukan pembangunan yang bertujuan untuk kesejahteraan masyarakat itu sendiri. Akan tetapi, pada prakteknya, beberapa tahun terakhir penerimaan pajak masih rendah. Bukan saja penerimaan pajak nasional yang belum optimal, rasio pajak juga mengalami penurunan. Tingkat kepatuhan masyarakat Indonesia dapat dilihat dari tingkat tax ratio yaitu $11 \%$, jika dibandingkan dengan negara negara tetangga Malaysia yang di atas $14 \%$ sampai $15 \%$, Vietnam dan Singapura $16 \%$. Pemungutan pajak itu sendiri masih memiliki banyak halangan dan tantangan yang berasal dari masyarakat itu sendiri, misalnya ; kesadaran akan membayar pajak masih kurang dalam masyarakat, artinya kesadaran wajib pajak berpengaruh terhadap kepatuhan wajib pajak (Safri, 2013), kemudian krisis kepercayaan publik pada pemerintah dan juga pemahaman akan perpajakan itu sendiri masih sangat kurang baik dari segi perhitungan, pembayaran sampai pada pelaporannya (dalam hal ini Menghitung Pajak Sendiri - Self Assessment System), sehingga tak jarang menimbulkan hambatan dalam pembayaran pajak itu sendiri.

Salah satu sumber untuk melaksanakan pembangunan nasional adalah penerimaan pajak yang mencapai $75 \%$ penerimaan negara saat ini, dengan adanya pajak maka negara dapat melakukan pembangunan yang bertujuan untuk kesejahteraan masyarakat itu sendiri. Dominasi pajak sumber penerimaan merupakan satu hal yang sangat wajar, ketika sumber daya alam, khususnya minyak bumi tidak bisa lagi diandalkan. Penerimaan dari suatu sumber daya alam mempunyai umur relatif terbatas yang suatu saat akan habis dan tidak bisa diperbaharui lagi. Hal ini berbeda dengan pajak, sumber penerimaan ini mempunyai umur tidak terbatas, apalagi seiring dengan bertambahnya jumlah penduduk, dan perubahan 
struktur ekonomi dari ekonomi agragris ke ekonomi industri maka akan semakin besar pula penerimaan negara dari sektor pajak (Darmayanti, 2012). Pada kenyataannya kesadaran dan kepedulian sukarela Wajib Pajak sangat sulit untuk diwujudkan seandainya tidak dipaksakan dengan undang undang dan sanksi (Dharma dan Ariyanto, 2014), artinya masyarakat dituntut untuk membayar pajak guna membangun perekonomian nasional. Pemungutan pajak itu sendiri masih memiliki banyak halangan dan tantangan yang berasal dari masyarakat itu sendiri, misalnya ; kesadaran akan membayar pajak masih kurang dalam masyarakat, krisis kepercayaan publik pada pemerintah dan juga pemahaman akan perpajakan itu sendiri masih sangat kurang meskipun pemerintah telah melakukan reformasi perpajakan dengan diterbitkannya Undang-Undang Nomor 36 Tahun 2008 tentang Ketentuan Umum dan Tata Cara Perpajakan. Masalah yang sering muncul, baik dari segi perhitungan, pembayaran sampai pada pelaporannya (dalam hal ini Menghitung Pajak Sendiri - Self Assessment System), sehingga tak jarang menimbulkan hambatan dalam pembayaran pajak itu sendiri.

Tingkat kepatuhan wajib pajak dalam melaporkan pajaknya masih rendah, kisaran 605$70 \%$ dan itupun masih didominasi oleh wajib pajak orang pribadi karyawan nukan pajak pengusah. Kelurahan Malendeng Kecamatan Paal 2 Kota Manado sebagai bagian dari daerah otonomi menarik untuk diamati secara khusus mengingat jumlah Wajib Pajak, pajak Bumi dan Bangunan berjumlah 1.305, namun realisasi PBB hanya berkisar 60,53\%, selain itu kelurahan Malendeng memiliki potensi penerimaan pajak dari berbagai sektor, yaitu dari sektor peternakan, industri kecil dan kerajinan rumah tangga, sektor industi menengah dan besar dan sektor jasa serta penerimaan pajak atas penguasaan aset ekonomi masyarakat. Proses menuju kepatuhan yang tinggi merupakan upaya yang berkelanjutan, tidak akan berhenti. Karena semakin tinggi tingkat kepatuhan pajak, baik secara formal atau material, maka akan memperbesar basis pemajakan. Ini berakibat akan semakin besar penerimaan pajak yang dapat dihimpun.

Kepatuhan wajib pajak mencakup kepatuhan mencatat atau membukukan transaksi usaha, kepatuhan melaporkan kegiatan usaha sesuai peraturan yang berlaku, serta kepatuhan terhadap semua aturan perpajakan lainnya. Di antara ketiga jenis kepatuhan tersebut, yang paling mudah diamati adalah kepatuhan melaporkan kegiatan usaha, karena seluruh wajib pajak berkewajiban menyampaikan laporan kegiatan usahanya setiap bulan dan/atau setiap tahun dalam bentuk menyampaikan Surat Pemberitahuan (SPT) dalam setiap masa atau Tahunannya.Beberapa wajib pajak mempunyai kepatuhan yang buruk dengan tidak membuat dan menyampaikan laporan kegiatan usaha secara periodik secara benar, lengkap dan jelas, baik laporan bulanan atau masa maupun tahunan. Yang memprihatinkan adalah wajib pajak semacam ini berjumlah paling banyak dari seluruh wajib pajak terdaftar. Patut menjadi perhatian lebih serius bagi Ditjen Pajak agar masalah ini bisa diatasi dan diawasi secara lebih.

Beberapa faktor yang menyebabkan rendahnya kepatuhan wajib pajak antara lain ketidakpuasan masyarakat terhadap pelayanan publik, pembangunan infrastruktur yang tidak merata, dan banyaknya kasus korupsi yang dilakukan pejabat tinggi. Salah satu penyebabnya adalah masyarakat kurang merasakan manfaat dari pajak yang telah dibayar, misalnya masih banyaknya jalan yang rusak dan sarana publik yang tidak memadai serta kasus korupsi yang kerap mendera pejabat eksekutif pemerintahan baik pusat ataupun daerah. Berdasarkan studi dari Dana Moneter Internasional (IMF) menyatakan bahwa rasio pajak di Indonesia rendah, alasan utamanya karena peraturan perpajakan di Indonesia yang sangat rumit, dan berdampak pada pemenuhan target pajak semakin sulit. Berdasarkan hasil pengisian kuesioner, kelompok pengusaha kecil di Kelurahan Malendeng menghadapi masalah pajak adalah teknis penghitungan dan pelaporan perpajakanyang rumit, ditambah dengan minimnya pengetahuan masyarakat khususnya pengusaha kecil tentang pajak dalam hal ini Pajak Penghasilan, sedangkan sistem perpajakan atas pajak ini adalah menghitung pajak sendiri (Self Assessment System), hal ini sejalan dengan penelitian Azizah, Rahayu dan Jauhari (2015). 
Masyarakat kelurahan Malendeng diberikan pengetahuan tentang perpajakan khususnya pajak penghasilan sehubungan dengan usaha. Cara penghitungan pajak penghasilan dijelaskan dengan contoh kasus dari usaha masyarakat. Penghasilan kotor sebulan dikali dengan tarif pajak.

$$
\text { Pajak terutang }=\text { Penghasilan kotor } \mathrm{x} 0,5 \%
$$

Misalnya Tuan $\mathrm{Z}$ adalah seorang pedagang kerajinan rotan yang memiliki penghasilan kotor penjualan pada 1 tahun terakhir adalah Rp 217.500.000, dengan rincian sebagai berikut.

Tabel 1. Perhitungan PPh Final berdasarkan PP No 23 Tahun 2018

\begin{tabular}{llll}
\hline Bulan & Omzet & PPh Final \\
\hline Januari & Rp. 18.000 .000 & Rp. 90.000 \\
Pebruari & Rp. 19.000 .000 & Rp. 95.000 \\
Maret & Rp. 16.500 .000 & Rp. 82.500 \\
April & Rp. 18.000 .000 & Rp. 90.000 \\
Mei & Rp. 19.000 .000 & Rp. 95.000 \\
Juni & Rp. 18.750 .000 & Rp. 93.750 \\
Juli & Rp. 17.000 .000 & Rp. 85.000 \\
Agustus & Rp. 18.250 .000 & Rp. 91.250 \\
September & Rp. 18.100 .000 & Rp. 90.500 \\
Oktober & Rp. 17.400 .000 & Rp. 87.000 \\
November & Rp. 18.300 .000 & Rp. 91.500 \\
Desember & Rp. 19.200 .000 & Rp. 96.000 \\
\hline Total & Rp.217.500.000 & Rp.1.087.500 \\
\hline
\end{tabular}

Jumlah peredaran bruto atas penghasilan dari usaha setiap bulan merupakan dasar pengenaan pajak yang digunakan untuk menghitung Pajak Penghasilan yang bersifat final. Peredaran bruto yang dijadikan dasar pengenaan pajak merupakan imbalan atau nilai pengganti berupa uang atau nilai uang yang diterima atau diperoleh dari usaha, sebelum dikurangi potongan penjualan, potongan tunai, dan/atau potongan sejenis. Pajak Penghasilan terutang dihitung berdasarkan tarif dikalikan dengan dasar pengenaan pajak.

Pajak Penghasilan terutang dilunasi dengan cara: disetor sendiri oleh Wajib Pajak yang memiliki peredaran bruto tertentu; atau dipotong atau dipungut oleh Pemotong atau Pemungut Pajak dalam hal Wajib Pajak bersangkutan melakukan transaksi dengan pihak yang ditunjuk sebagai Pemotong atau Pemungut Pajak.Penyetoran sendiri Pajak Penghasilan terutang wajib dilakukan setiap bulan.Pemotongan atau pemungutan Pajak Penghasilan terutang oleh Pemotong atau Pemungut Pajak untuk setiap transaksi dengan Wajib Pajak yang dikenai Pajak Penghasilan yang bersifat final berdasarkanPeraturan Pemerintah ini

\section{KESIMPULAN DAN SARAN}

\subsection{Kesimpulan}

Guna meningkatkan kesadaran masyarakat tentang Pajak Penghasilan, perlu dilakukan sosialisasi dan pelatihan penghitungan pajak yang terkait dengan usaha masyarakat. Karena UMKM sebagian besar belum memahami ketentuan perpajakan. Selain itu perubahan peraturan perpajakan yang sering kali terjadi menyebabkan masyarakat tidak mengetahui tarif pajak yang berlaku saat ini. 


\subsection{Saran}

Perlu adanya penyuluhan dan pelatihan tentang Pajak Penghasilan khususnya terhadap UMKM yang tersebar di Kelurahan Malendeng. Penyuluhan ini dapat meningkatkan kesadaran masyarakat terhadap pajak. Karena salah satu penyebab kurangnya penerimaan dari pajak adalah karena kurangnya pengetahuan masyarakat tentang pajak.

\section{DAFTAR PUSTAKA}

Azizah, N. N., Rahayu, S. M., dan Jauhari, A. 2015. Analisis Penghitungan, Pencatatan dan Pelaporan Pajak Penghasilan Pasal 23 atas Jasa Outsourcing. Jurnal Perpajakan (JEJAK), (1), 1-8.

Darmayanti, N. 2012. Analisis Perhitungan Pajak Pertambahan Nilai (PPN) pada CV Sarana Teknik Kontrol Surabaya. Jurnal manajemen dan Akuntansi, 1(3), 29-45.

Dharma, M. T., dan Ariyanto, S. 2014. Analisis Faktor-Faktor yang Mempengaruhi Tingkat Kepatuhan Wajib Pajak Orang Pribadi di Lingkungan Kantor Pelayanan Pajak Pratama, Tigaraksa Tangerang. Binus Business Review, 5(2), 497-509.

Mardiasmo. 2016. Perpajakan. Edisi Revisi. Penerbit Andi.Yogyakarta.

Nugraheni A. D. 2015. Faktor-Faktor yang Mempengaruhi Kepatuhan Wajib Pajak Orang Pribadi (Studi Empiris pada Wajib Pajak di Kota Magelang). Skripsi Fakultas ekonomika dan Bisnis Universitas Diponegoro Semarang.

Republik Indonesia Undang-Undang Nomor 28 Tahun 2007 tentang Ketentuan Umum dan Tata Cara Perpajakan

Republik Indonesia Undang-Undang Nomor 36 Tahun 2008 Tentang Perubahan Ketiga Atas Undang-Undang Nomor 7 Tahun 1983 Tentang Pajak Penghasilan

Republik Indonesia Undang-Undang Nomor 42 Tahun 2009 tentang Pajak Pertambahan Nilai.

Undang-Undang Republik Indonesia. UU No.42 Tahun 2009 Tentang Perubahan Ketiga Atas

Undang-Undang Nomor 8 Tahun 1983 Tentang Pajak Pertambahan Nilai Barang dan Jasa dan Pajak Penjualan Atas Barang Mewah Republik Indonesia Undang-Undang Nomor 36 Tahun 2008 tentang Ketentuan Umum dan Tata Cara Perpajakan

Peraturan Pemerintah Republik Indonesia Nomor 23 tahun 2018 tentang pajak penghasilan atas penghasilan dari usaha yang diterima atau diperoleh wajib pajak yang memiliki peredaran bruto tertentu

Resmi, S. 2011. Perpajakan: Teori dan Kasus. Penerbit Salemba Empat, Jakarta.

Safri, R. D. 2013. Pengaruh Kesadaran Wajib Pajak Terhadap Kepatuhan Wajib Pajak Orang Pribadi Yang Melakukan Pekerjaan Bebas. Skripsi Fakultas Ekonomi Universitas Negeri Yogyakarta.

Waluyo. 2011. Perpajakan Indonesia. Penerbit Salemba Empat. Jakarta. 